Огляди літератури, оригінальні дослідження, погляд на проблему, випадок з практики, короткі повідомлення УдК 616.84-06:616-008.9-02:616.37-002.2

DOI 10.11603/1811-2471.2020.v.i4.11753

\title{
ВПЛИВ КУРІННЯ НА ЗАГАЛЬНОКЛІНІЧНІ ТА БІОХІМІЧНІ ПАРАМЕТРИ ПАЦІЄНТІВ ІЗ ХРОНІЧНИМ ПАНКРЕАТИТОМ
}

\author{
○Л. С. Бабінець, 3. я. Онуфрик \\ Тернопільський національний медичний університет імені І. Я. Горбачевського МОз України
}

РЕзЮМЕ. Хронічний панкреатит (ХП) у курців спостерігається в 2 рази частіше, ніж у некурців, а ризик розвитку захворювання зростає залежно від кількості викурених сигарет.

Мета - дослідити вплив куріння на основні загальноклінічні та біохімічні параметри та показники ендотоксикозу в пацієнтів із хронічним панкреатитом.

Матеріал і методи. Обстежено 64 амбулаторних пацієнти поза загостренням: 21 - з ізольованим ХП і 43 - із ХП на тлі супутнього куріння. Діагноз встановлювали за загальноприйнятим методом, анамнез куріння розраховували в одиницях «пачки-роки» (одна пачка складала 20 цигарок). Параметри загальноклінічного і біохімічного аналізу крові визначали за загальноприйнятими у клініці методиками. Оцінку ендогенної інтоксикації (ЕІ) проводили за рівнями молекул середньої маси (MCM1 і MCM2), рівнем EI (PEI), а також вмістом циркулюючих імунних комплексів (ЦІК) у сироватці крові.

Результати. Куріння негативно впливало на клінічний перебіг хронічного панкреатиту поза загостренням за рахунок наявності проявів диспепсичного (на 14,4 \%), больового (на 7,5 \%) і астено-невротичного (на 31,1 \%) синдромів у більшої кількості пацієнтів-курців, порівняно некурцями $(p<0,05)$.

Поєднання ХП і куріння сприяло поглибленню анемічного синдрому (наявність анемії 88,37 \% у групі курців проти 71,42 \% у групі некурців; латентної анемії- відповідно 34,88 \% проти 23,80 \%; легкого ступеня - 41,86 \% проти 47,61 \%; середнього ступеня - 11,63 \% у групі курців при відсутності такої у групі некурців) і виснаженню вісцерального пулу білка за показником загального білка, а також більшій інтенсивності запального процесу у пЗ за вмістом амілази у крові, порівняно з аналогічними параметрами пацієнтів-некурців.

Висновки. Встановили вірогідно вищий рівень ендогенної інтоксикації пацієнтів з хронічним панкреатитом стосовно групи контролю (на 60,71 \% - у некурців і на 102,19 \% - у курців), вищий вміст МСМ1 стосовно групи здорових у групі курців проти такого у некурців - на 42,46 \% проти 30,20\%, а також вищий рівень циркулюючих імунних комплексів у групі курців проти такого у некурців $(p<0,05)$. Це довело ускладнювальний вплив куріння на перебіг хронічного панкреатиту, а також глибину загальноклінічних і біохімічних лабораторних параметрів і показників ендотоксикозу.

КЛючОВІ СЛОВА: хронічний панкреатит; куріння; ендогенна інтоксикація; клінічні синдроми; анемія.

Вступ. Хронічний панкреатит (ХП) у курців спостерігається в 2 рази частіше, ніж у некурців, а ризик розвитку захворювання зростає залежно від кількості викурених сигарет, причому в більш молодому віці, що сприяє виснаженню запасів вітамінів С і А, а також знижує вміст інших антиоксидантів, що зумовлює пошкодження тканини підшлункової залози (ПЗ) вільними радикалами $[1,5$, $16,21]$. Низка дослідників дійшли до висновку, що куріння, разом з алкоголем, $\epsilon$ одним із найбільш значимих етіологічних факторів розвитку ХП $[9,15,17,21]$.

Дослідження останніх років довели, що секреція шлунково-кишкового тракту (ШКТ) під впливом куріння дуже варіює [7]. Нікотин впливає на екзокринну секрецію ПЗ, адже зміна рівнів базальної циркуляції гормонів ШКТ - холецистокініну, сироваткових ферментів (амілази і ліпази), панкреатичної секреторної функції - пов' язана зі змінами функціональної активності ПЗ $[3,15]$. Зниження сироваткової антитрипсинової активності може значно впливати на легені, печінку і ПЗ як на органи-мішені, де цей фермент або синтезується, або реалізує свій вплив. Дослідження, проведені на щурах і мишах, показали, що основними морфологічними змінами ПЗ під впливом нікотину, церулеїну і дієти (нестача холіну і надлишок метіоніну) $\epsilon$ цитоплазматична вакуолізація, клітинний інтерстиціальний набряк, фрагментація ядер $[3,7]$. Поява цитоплазматичних вакуолей в екзокринній частині ПЗ - перша фаза їі пошкодження. Вакуолі містять травні і лізосомальні ферменти, локалізовані в їхньому кислому середовищі. При активації ензими перетворюються на активні протеази, що сприяють ушкодженню ПЗ. Елементи, що містяться в панкреатичних клітинах, $є$ факторами синтезу, зберігання й переміщення (сумісної локалізації) травних ферментів, задіяних у розвитку ХП [12]. Під впливом куріння знижується панкреатична секреція бікарбонатів, що призводить до підвищення в'язкості панкреатичного соку $[12,13]$.

Куріння $\epsilon$ загальновідомим фактором виникнення злоякісних пухлин різних локалізацій, особливо при тривалому анамнезі його, що посилює негативний прогноз щодо розвитку малігнізації при ХП, оскільки доведено, що ХП - це передраковий стан: 20-річний перебіг цієї патології підвищує ризик раку ПЗ у 5 разів $[1,5,16,19,20]$. 
Огляди літератури, оригінальні дослідження, погляд на проблему, випадок з практики, короткі повідомлення

Тютюнова залежність включена до рубрики MKX-10 «Психічні та поведінкові розлади внаслідок вживання психоактивних речовин» $[6,7]$. За останніми даними, в Україні 45 \% чоловіків і 8 \% жінок курить щодня $[1,5,12]$. Тому вивчення впливу куріння на клінічний перебіг ХП, лабораторні параметри пацієнтів і показники якості життя при ХПє актуальним.

Мета - дослідити вплив куріння на основні загальноклінічні та біохімічні параметри і показники ендотоксикозу пацієнтів із хронічним панкреатитом.

Матеріал і методи. Обстежено 64 амбулаторних пацієнти у фазі нестійкої та стійкої ремісії: 21 із ізольованим ХП і 43 - із ХП на тлі супутнього куріння; контрольну групу склали 30 практично здорових осіб (пацієнти перебували під спостереженням у Заліщицькому Центрі ПМСД Тернопільської області). Джерелом інформації слугували «Медичні карти амбулаторного хворого» (ф. 025/о). Вік хворих - від 25 до 70 років, у середньому (47士13) років; 28 чоловіків і 36 жінок.

Діагноз ХП встановлювали за клініко-статистичною класифікацією (Інститут гастроентерології НАМН України, 2003), а також згідно з Наказом МO3 України № 638 від 10.09.2014 «Про затвердження та впровадження медико-технологічних документів зі стандартизації медичної допомоги при хронічному панкреатиті» на підставі анамнезу, клінічних проявів, лабораторних даних, результатів ультразвукового дослідження органів черевної порожнини $[4,6]$.

Анамнез куріння розраховували в одиницях «пачки-роки» (одна пачка складала 20 цигарок), яку визначали за формулою:

Кількість пачко/років = кількість цигарок за день × число років /20.

Якщо даний показник перевищував 25 пачко/ років, то хворого відносили до групи «злісних» курців, досягав 10 пачко/років - до категорії «безумовних» курців $[3,6]$.
Усім хворим були проведені стандартні загальноклінічні обстеження: загальний аналіз крові та сечі, розгорнутий біохімічний аналіз крові.

Загальний аналіз крові проводили на гемоаналізаторі із визначенням концентрації гемоглобіну в крові гемоглобінціанідним методом 3 реєстрацією оптичної густини на спектрофотометрі СФ-44 при довжині хвилі 560 нм у кюветі з довжиною шляху 1 см. Ступінь тяжкості анемії визначали за критеріями А. Б. Альперіна (1983), Ю. Г. Мітєрєва і Л. Н. Вороніної (1992) [6, 9].

Рівень а-амілази в крові та а-амілази (діастази) в сечі визначали за загальноприйнятими в клініці методами. За норму вважали: рівень а-амілази в крові (за методом Каравея) - 12,0-32,0 мг/(год×мл) і а-амілази (діастази) в сечі - 20,0-160,0 мг/(год×мл). Показники білкового обміну в сироватці крові визначали за допомогою наборів Lachema такими методами: загальний білок - за біуретовим методом, альбумін - за реакцією з бром крезолом зеленим. Вміст глюкози в крові визначали натще глюкозооксидазним методом, вважаючи за норму показник 4,44-5,55 ммоль/л $[10,14]$.

Оцінку ендогенної інтоксикації (ЕІ) проводили за рівнями молекул середньої маси (MCM 1 $\mathrm{MCM}_{2}$ ) за методом Габріеляна при довжинах хвиль 254 нм і 280 нм. Рівень ЕI (PEI) визначали за методом Тогайбаєва, в основі якого лежить уявлення про еритроцити як про універсальний адсорбент. Стан імунної активності визначали за рівнем циркулюючих імунних комплексів (ЦІК), що визначали методом селективної преципітації із наступним фотометруванням $[2,8,11]$.

Результати й обговорення. Аналіз групи хворих на ХП із супутнім курінням засвідчив, що серед них переважали "злісні» (39,50 \%) і «безумовні» (34,88 \%) курці (табл. 1). Це дозволяє вважати достовірним вплив куріння на стан здоров'я пацієнтів з ХП, що засвідчує вірогідність отриманих даних щодо впливу куріння на показники, що аналізуються.

Таблиця 1. Розподіл активних курців із хронічним панкреатитом за стажем куріння

\begin{tabular}{|l|c|c|c|}
\hline \multirow{2}{*}{ Кількість пацієнтів } & \multicolumn{3}{|c|}{ Стаж куріння, пачки-роки } \\
\cline { 2 - 4 } & до 10 & $10-20$ & більше 20 \\
\hline Абсолютна, особи & 11 & 15 & 39,50 \\
\hline Відносна, \% & 25,58 & 34,88 & 39 \\
\hline
\end{tabular}

Аналіз клінічних синдромів довів, що куріння негативно впливало на клінічну симптоматику ХП у фазі нестійкої ремісії за рахунок більш інтенсивних проявів диспепсичного (на 14,4 \%), больового (на 7,5 \%) і астено-невротичного (на 31,1 \%) синдромів, порівняно з некурцями $(p<0,05)$.

При оцінці результатів загальноклінічних і біохімічних обстежень (табл. 2) пацієнтів з ХП обох груп було виявлено їх достовірну відмінність стосовно таких у здорових людей.

При ХП в обох групах було виявлено анемію легкого ступеня, відносне зниження кількості еритроцитів, відносне підвищення кількості лейкоцитів і ШОЕ, зниження вмісту білка в крові, підвищені рівні амілази в крові і діастази сечі. Це дозволило зробити висновок про те, що у хворих на ХП пору- 
Огляди літератури, оригінальні дослідження, погляд на проблему, випадок з практики, короткі повідомлення

Таблиця 2. Порівняльний аналіз загальноклінічних і біохімічних показників при хронічному панкреатиті залежно від наявності куріння

\begin{tabular}{|c|c|c|c|}
\hline \multirow[b]{2}{*}{ Показник } & \multicolumn{3}{|c|}{ Група пацієнтів з ХП } \\
\hline & контроль $(n=30)$ & пацієнти із ХП (n=21) & $\begin{array}{c}\text { пацієнти із ХП і курінням } \\
(\mathrm{n}=43)\end{array}$ \\
\hline Еритроцити, 1012/л & $4,35 \pm 0,05$ & $3,54 \pm 0,06^{*}$ & $3,37 \pm 0,04 * \wedge$ \\
\hline Гемоглобін, г/л & $130,82 \pm 1,21$ & $114,42 \pm 1,59 *$ & $100,11 \pm 1,43^{* \wedge}$ \\
\hline Лейкоцити, $10^{9} / л$ & $5,71 \pm 0,10$ & $6,35 \pm 0,20 *$ & $7,28 \pm 0,35 * \wedge$ \\
\hline ШОЕ, мм/год & $5,58 \pm 0,36$ & $8,47 \pm 0,56^{*}$ & $10,23 \pm 0,54 * \wedge$ \\
\hline Загальний білок, г/л & $84,03 \pm 0,31$ & $72,42 \pm 1,79 *$ & $67,84 \pm 0,58^{* \wedge}$ \\
\hline Глюкоза крові, ммоль/л & $4,74 \pm 0,10$ & $4,82 \pm 0,12$ & $4,78 \pm 0,14$ \\
\hline Амілаза крові, мг/год×мл & $28,76 \pm 0,82$ & $43,26 \pm 1,21 *$ & $48,78 \pm 0,20 * \wedge$ \\
\hline Діастаза сечі, г/(год×л) & $74,85 \pm 3,64$ & $147,34 \pm 7,94^{*}$ & $155,93 \pm 4,57 *$ \\
\hline
\end{tabular}

\section{Примітки:}

1. * $p<0,05$ - різниця показників достовірна порівняно з такими у групі контролю;

2. ^ $\mathrm{p}<0,05$ - різниця показників достовірна порівняно з такими у групі пацієнтів із ХП.

шення різних ланок обміну речовин і торпідний запальний процес проявлялися навіть у фазі ремісії. Встановлено достовірно глибші зміни параметрів пацієнтів з ХП і супутнім курінням, порівняно з такими без куріння. За отриманими даними, поєднання ХП і куріння сприяло поглибленню анемічного синдрому і виснаженню вісцерального пулу білка за показником загального білка у сироватці крові, а також більш значній інтенсивності запального процесу у ПЗ за вмістом амілази у крові. Слід зазначити, що кількість лейкоцитів і ШОЕ були вірогідно вищими у групі курців, проте вони не виходили за межі коридору норми.

У результаті аналізу параметрів анемії за даними загального аналізу крові при ХП залежно від наявності куріння встановлено, що серед 43 обстежених пацієнтів із ХП у поєднанні із курінням анемія різного ступеня тяжкості (рівень гемоглобіну нижчий за 119 г/л) була виявлена у 38 осіб (88,37 \%). Нормальний рівень гемоглобіну (120130 г/л) спостерігався лише у 5 пацієнтів (11,63\%). Латентну анемію (рівень гемоглобіну 110-119 г/л) виявили у 15 пацієнтів (34,88\%), анемію легкого ступеня (рівень гемоглобіну 90-109 г/л) - у 18 пацієнтів $(41,86 \%)$ та анемію середньої тяжкості - у 5 пацієнтів (11,63\%). Анемії тяжкого ступеня виявлено не було. У групі пацієнтів із ХП без куріння анемію було діагностовано у 15 осіб $(71,42 \%)$, із них латентну анемію - у 5 хворих (23,8 \%), анемію легкого ступеня - у 10 хворих (47,61\%). Анемії середньої тяжкості та тяжкої виявлено не було. На нашу думку, причиною анемії при ХП у курців $\epsilon$ накопичення сироваткових цитокінів і хемокінів, які токсично діють на еритроцити, скорочуючи при цьому тривалість їх життя, порушуючи мобілізацію і утилізацію заліза, знижуючи відповідь кісткового мозку на дію еритропоетину. Крім того, згідно з літературними даними, відомо, що анемічний синдром $є$ одним із проявів куріння, який прогресує при поєднаному перебігу обох захворювань $[9,18]$.

Згідно із сучасними уявленнями, посилення El $€$ однією з ланок патогенезу як ХП, так і куріння, а також предиктором розвитку ТН при ХП. Результати дослідження змін параметрів ЕІ у хворих із поєднанням ХП і куріння наведені у таблиці 3.

Таблиця 3. Показники ендогенної інтоксикації при хронічному панкреатиті залежно від наявності куріння

\begin{tabular}{|c|c|c|c|}
\hline \multirow{2}{*}{ Показник ЕІ } & \multicolumn{3}{|c|}{ Група пацієнтів з ХП } \\
\cline { 2 - 4 } & контроль $(\mathrm{n}=30)$ & пацієнти із ХП (n=21) & пацієнти із ХП і курінням (n=43) \\
\hline РЕІ, \% & $28,13 \pm 1,18$ & $45,20 \pm 2,84^{*}$ & $57,16 \pm 3,04^{* \wedge}$ \\
\hline MCM $_{1}$ & $335,71 \pm 1,96$ & $437,12 \pm 12,57^{*}$ & $478,26 \pm 15,05^{* \wedge}$ \\
\hline МСМ $_{2}$ & $147,74 \pm 1,33$ & $219,64 \pm 12,52^{*}$ & $232,47 \pm 5,69^{*}$ \\
\hline ЦІК, ум.од. & $64,451,18$ & $169,44 \pm 3,72^{*}$ & $198,61 \pm 6,38^{* \wedge}$ \\
\hline
\end{tabular}

Примітки:

1. * $\mathbf{p}<0,05$ - різниця показників достовірна порівняно з такими у групі контролю;

2. ^ $p<0,05$ - різниця показників достовірна порівняно з такими у групі пацієнтів із ХП.

Встановили вірогідне зростання РЕІ у хворих на ХП обох груп, порівняно з групою контролю: на $60,71 \%$ у некурців і на 102,19 \% у курців. Отже, ку- ріння вірогідно негативно впливало на даний показник $(p<0,05)$. Аналіз вмісту в крові MCM $_{1}$ у курців і некурців з ХП виявив значне їх підвищення в 
Огляди літератури, оригінальні дослідження, погляд на обох групах. Проте, спостерігали вищий вміст МСM, стосовно групи здорових у групі курців, проти такого у некурців, - на 42,46 \% проти 30,20 \%. Показник MCM $_{2}$ був підвищений в обох групах, проте вірогідного впливу куріння на нього виявлено не було.

Також при ХП, як із супутнім курінням, так і без нього, було виявлено достовірно вищий рівень ЦІК, порівняно з групою контролю, що свідчило про наявність торпідного запального процесу при цій патології навіть поза загостренням. При ХП із супутнім курінням рівень ЦІК був достовірно вищим від такого показника у групі некурців. На нашу думку, підвищений рівень ЦІК при ХП із курінням пов'язаний із накопиченням продуктів катаболізму білка при деструктивно-дистрофічних процесах у Пз і бронхолегеневій системі у курців, адже показник ЦІК є індикатором ЕІ й ознакою активації імунної системи, що також посилюється при коморбідності ХП і куріння.

Висновки. 1. Куріння негативно впливає на клінічний перебіг хронічного панкреатиту поза загостренням за рахунок наявності проявів диспепсичного (на 14,4 \%), больового (на 7,5 \%) і астено-невротичного (на 31,1 \%) синдромів у більшої кількості пацієнтів-курців, порівняно з некурцями $(p<0,05)$;

2. Поєднання ХП і куріння сприяє поглибленню анемічного синдрому (наявність анемії 88,37 \% у групі курців проти 71,42 \% у групі некурців; латентної анемії - відповідно 34,88 \% проти 23,80 \%; легкого ступеня - 41,86 \% проти 47,61 \%; середнього ступеня - 11,63 \% у групі курців при відсутності такої у групі некурців) і виснаженню вісцерального пулу білка за показником загального білка, а також більш значній інтенсивності запального процесу у ПЗ за вмістом амілази у крові, порівняно з аналогічними параметрами пацієнтів-некурців;

3. Рівень ендогенної інтоксикації пацієнтів з хронічним панкреатитом вірогідно вищий стосовно групи контролю (на 60,71 \% - у некурців і на $102,19 \%$ - у курців), вміст МСМ стосовно групи здорових у групі курців вищий проти такого у некурців - на 42,46 \% проти 30,20\%, а також рівень циркулюючих імунних комплексів у групі курців вищий проти такого у некурців $(p<0,05)$.

Перспективи подальших досліджень. Плануємо запропонувати і науково обґрунтувати методики корекції куріння при хронічному панкреатиті.

\section{ЛІТЕРАТУРА}

1. Бабінець Л. С. Клініко-патогенетичне обґрунтування впливу тютюнопаління на клінічний перебіг хронічного панкреатиту / Л. С. Бабінець, 3. Я. Пінкевич // Здоров' я України. - 2013. - № 4. - С. 46-48.

2. The effect of the proteolisis' system activity for the trophological status of patients with osteoarthrosis and excretory insufficiency of pancreas / L. S. Babinets, I. M. Halabitska, Yu. Ya. Kotsaba [et al.] // Wiadomosci lekarskie (Warshav, Poland: 1960). - 2018. - Vol. LXXI (2 ch. 1). - P. 273-276.

3. Пікас О. Б. Куріння цигарок серед населення та його роль у розвитку захворювань / О. Б. Пікас // Вісник проблем біології і медицини, -2016. -Вип. 1, т. 1, № 126. C. 48-52.

4. Наказ МОЗ України від 10.09.2014 № 638 «Про затвердження та впровадження медико-технологічних документів зі стандартизації медичної допомоги при хронічному панкреатиті». [Електронний ресурс]. - Режим доступу: http://www.moz.gov.ua/ua/portal/ dn_20140910_0638.html.

5. Болезни поджелудочной железы как одна из ведущих проблем гастроэнтерологии и абдоминальной хирургии (современная эпидемиология) / Ю. М. Степанов, Н. Г. Гравировская, И. Ю. Скирда, О. П. Петишко // Гастроентерология. - 2014. - № 3. - С. 7-14.

6. Сучасні класифікації та стандарти лікування розповсюджених захворювань внутрішніх органів / за ред. Ю. М. Мостового. Вид. 26-е, доп. і переро6. - Вінниця, 2012. - 792 с.
7. Smoking as a cofactor for causation of chronic pancreatitis: a meta-analysis / A. Andriulli, E. Botteri, P. L. Almasio [et al.] // Pancreas. - 2010. - Vol. 39 (8). - P. 1205-1210.

8. Babinets L. S. The trophological status of patients with osteoarthrosis and excretory insufficiency of pancreas / L. S. Babinets, I. M. Halabitska // Health of Society. 2019. - Vol. 8 (2). - P. 41-44.

9. Mortality, cancer, and comorbidities associated with chronic pancreatitis: a Danish nationwide matched-cohort study / U. C. Bang, T. Benfield, L. Hyldstrup [et al.] // Gastroenterol. - 2014. - Vol. 146 (4). - P. 989-994.

10. The Spanish Pancreatic Club's recommendations for the diagnosis and treatment of chronic pancreatitis: part 2 (treatment) / E. de-Madaria, A. Abad-González, J. R. Aparicio [et al.] // Pancreatol. - 2013. - Vol. 13 (1). - P. 18-28.

11. Dutch Chronic Pancreatitis Registry (CARE): Design and rationale of a nationwide prospective evaluation and follow-up / U. Ahmed Ali, Y. Issa, H. van Goor [et al.] // Pancreatol. - 2015. - Vol. 15 (1). - P. 46-52.

12. Quality of life comparison between smokers and non-smokers with chronic pancreatitis / S. Han, B. Patel, M. Min [et al.] // Pancreatol. - 2018. - Vol. 2018. - P. 269-274.

13. English language version of the S3-consensus guidelines on chronic pancreatitis: definition, aetiology, diagnostic examinations, medical, endoscopic and surgical management of chronic pancreatitis / A. Hoffmeister, J. Mayerle, C. Beglinger [et al.] // Zeitschrift Gastroenterol. - 2015. - Vol. 53 (12). - P. 1447-1495. 
Огляди літератури, оригінальні дослідження, погляд на проблему, випадок з практики, короткі повідомлення

14. Evidence-based clinical practice guidelines for chronic pancreatitis / T. Ito, H. Ishiguro, H. Ohara [et al.] // J. Gastroenterol. - 2016. - Vol. 51 (2). - P. 85-92.

15. Alcohol and cigarette smoke components activate human pancreatic stellate cells: implications for the progression of chronic pancreatitis / A. T. K. Lee, Z. Xu, S. P. Pothula [et al.] // Alcohol. Clin. Exp. Res. - 2015. Vol. 39 (11). - P. 2123-2133.

16. Quality of life in chronic pancreatitis is determined by constant pain, disability/unemployment, current smoking, and associated co-morbidities / J. D. Machicado, S. T. Amann, M. A. Anderson [et al.] // Am. J. Gastroenterol. - 2017. - Vol. 112 (4). - P. 633-642.

17. Johnson C. D. Pancreatic disease: basic science and clinical management / C. D. Johnson, C. W. Imrie. London : Springer-verlag Ltd, 2014. - 490 p.

\section{REFERENCES}

1. Babinets, L.S., \& Pinkevych, Z.Ya. (2013). Klinikopatohenetychne obhruntuvannia vplyvu tiutiunopalinnia na klinichnyi perebih khronichnoho pankreatytu [Clinical and pathogenetic substantiation of the influence of smoking on the clinical course of chronic pancreatitis]. Zdorovia Ukrainy - Health of Ukraine, 4, 46-48 [in Ukrainian].

2. Babinets, L.S., Halabitska, I.M., Kotsaba, Yu.Ya., Borovyk, I.O., Migenko, B.O., Ryabokon, S.S., \& Tsybulska, L.S. (2018). The effect of the proteolisis' system activity for the trophological status of patients with osteoarthrosis and excretory insufficiency of pancreas. Wiadomosci lekarskie (Warshav, Poland: 1960), LXXI, (2 ch. 1), 273-276.

3. Pikas, O.B. (2016). Kurinnia tsyharok sered naselennia ta yoho rol u rozvytku zakhvoriuvan [Cigarette smoking among the population and its role in the development of diseases.]. Visnyk problem biolohii i medytsyny - Bulletin of Problems of Biology and Medicine, 1, 1, 126, 48-52 [in Ukrainian].

4. Order of the Ministry of Health of Ukraine from 10.09.2014 № 638 «Pro zatverdzhennia ta vprovadzhennia medyko-tekhnolohichnykh dokumentiv zi standartyzatsii medychnoi dopomohy pry khronichnomu pankreatyti» ["On approval and implementation of medical and technological documents for standardization of medical care for chronic pancreatitis"]. Nakaz MOZ Ukrainy vid 10.09.2014 № 638. Retrieved from: http://www.moz.gov.ua/ua/ portal/dn_20140910_0638.html.

5. Stepanov, Yü.M., Gravirovskaya, N.G., Skirda, I.Yu., \& Petishko, O.P. (2014). Bolezni podzheludochnoy zhelezy kak odna iz vedushchikh problem gastroenterologii i abdominalnoy khirurgii (sovremennaya epidemiologiya) [Diseases of the pancreas as one of the leading problems of gastroenterology and abdominal surgery (modern epidemiology)]. Gastroyenterologiya - Gastroenterology, 3, 7-14 [in Russian].

6. Mostovyi, Yu.M. (Ed.). (2012). Suchasni klasyfikatsii ta standarty likuvannia rozpovsiudzhenykh zakhvoriuvan vnutrishnikh orhaniv [Modern classifications and standards of treatment of common diseases of the internal organs]. 26th edn., suppl. and rev. Vinnytsia [in Ukrainian].

7. Andriulli, A., Botteri, E., Almasio, P.L., Vantini, I., Uomo, G., \& Maisonneuve, P. (2010). Smoking as a cofactor
18. Clube Português do Pâncreas recommendations for chronic pancreatitis: etiology, natural history, and diagnosis (Part I) / E. Rodrigues-Pinto, A. Caldeira, J. B. Soares [et al.] // GE Port J. Gastroenterol. - 2019. - Vol. 26 (5). - P. 346-355.

19. United European Gastroenterology evidence based guidelines for the diagnosis and therapy of chronic pancreatitis (HaPanEU) / J. M. Lohr, E. Dominquez-Munoz, J. Rosendahl [et al.] // United Eur. Gastroenterol. J. - 2017. Vol. 5 (2). - P. 1-47.

20. Chronic pancreatitis: an international draft consensus proposal for a new mechanistic definition / D. C. Whitcomb, L. Frulloni, P. Garg [et al.] // Pancreatol. - 2016. Vol. 16 (2). - P. 218-224.

21. Yadav D. The role of alcohol and smoking in pancreatitis / D. Yadav, D. C. Whitcomb // Nat. Rev. Gastroenterol. Hepatol. - 2010. - Vol. 7 (3). - P. 131-145.

for causation of chronic pancreatitis: a meta-analysis. Pancreas, 39 (8), 1205-1210.

8. Babinets, L.S., \& Halabitska, I.M. (2019). The trophological status of patients with osteoarthrosis and excretory insufficiency of pancreas. Health of Society, 8 (2), 41-44.

9. Bang, U.C., Benfield, T., Hyldstrup, L., Bendtsen, F., \& Beck Jensen, J.-E. (2014). Mortality, cancer, and comorbidities associated with chronic pancreatitis: a Danish nationwide matched-cohort study. Gastroenterol., 146 (4), 989994. DOI: https://doi.org/10.1053/j.gastro.2013.12.033.

10. de-Madaria, E., Abad-González, A., Aparicio, J.R., Aparisi, L., Boadas, J., Boix, E., ..., \& Martínez, J. (2013). The Spanish Pancreatic Club's recommendations for the diagnosis and treatment of chronic pancreatitis: part 2 (treatment). Pancreatol., 13 (1), 18-28.

11. Ahmed Ali, U., Issa, Y., van Goor H., van Eijck, C.H., Nieuwenhuijs, V.B., Keulemans, Y., ..., \& Boermeester, M.A. (2015). Dutch Chronic Pancreatitis Registry (CARE): Design and rationale of a nationwide prospective evaluation and follow-up. Pancreatol., 15 (1), 46-52.

12. Han, S., Patel, B., Min, M., Bocelli, L., Kheder, J., Wachholtz, A., \& Wassef, W. (2018). Quality of life comparison between smokers and non-smokers with chronic pancreatitis. Pancreatol., 2018, 269-274. DOI: https://doi. org/10.1016/j.pan.2018.02.012.

13. Hoffmeister, A., Mayerle, J., Beglinger, C., Büchler, M.W., Bufler, P., Dathe, K., ..., \& Lerch, M.M. (2015). English language version of the $\mathrm{S3}$-consensus guidelines on chronic pancreatitis: definition, aetiology, diagnostic examinations, medical, endoscopic and surgical management of chronic pancreatitis. Zeitschrift Gastroenterol., 53 (12), $1447-1495$

14. Ito, T., Ishiguro, H., Ohara, H., Kamisawa, T., Sakagami, J., Sata, N., ..., \& Shimosegawa, T. (2016). Evidencebased clinical practice guidelines for chronic pancreatitis. J. Gastroenterol., 51 (2), 85-92.

15. Lee, A.T.K., Xu, Z., Pothula, S.P., Patel, M.B., Pirola, R.C., Wilson, J.S., \& Apte, M.V. (2015). Alcohol and cigarette smoke components activate human pancreatic stellate cells: implications for the progression of chronic pancreatitis. Alcohol. Clin. Exp. Res., 39 (11), 2123-2133. 
Огляди літератури, оригінальні дослідження, погляд на проблему, випадок з практики, короткі повідомлення

16. Machicado, J.D., Amann, S.T., Anderson, M.A., Abberbock, J., Sherman, S., Conwell, D.L., ..., \& Yadav, D. (2017). Quality of life in chronic pancreatitis is determined by constant pain, disability/unemployment, current smoking, and associated co-morbidities. Am. J. Gastroenterol., 112 (4), 633-642.

17. Johnson, C.D., \& Imrie, C.W. (2014). Pancreatic disease: basic science and clinical management. London: Springer-verlag Ltd.

18. Rodrigues-Pinto, E., Caldeira, A., Soares, J.B., Antunes, T., Carvalho, J.R., Costa-Maia, J., ..., \& Moutinho-Ribeiro, P. (2019). Clube Português do Pâncreas recommendations for chronic pancreatitis: etiology, natural history, and diagnosis (Part I). GE Port J. Gastroenterol., 26 (5), 346355. DOI:10.1159/000497388.
19. Lohr, J.M., Dominquez-Munoz, E., Rosendahl, J., Besselink, M., Mayerle, J., Lerch, M.M., ..., \& Bruno, M. (2017). United European Gastroenterology evidence based guidelines for the diagnosis and therapy of chronic pancreatitis (HaPanEU). United Eur. Gastroenterol. J., 5 (2), 1-47.

20. Whitcomb, D.C., Frulloni, L., Garg, P., Greer, J.B., Schneider, A., Yadav, D., \& Shimosegawa, T. (2016). Chronic pancreatitis: an international draft consensus proposal for a new mechanistic definition. Pancreatol., 16 (2), 218-224.

21. Yadav, D., \& Whitcomb, D.C. (2010). The role of alcohol and smoking in pancreatitis. Nat. Rev. Gastroenterol. Hepatol., 7 (3), 131-145.

\section{ВЛИЯНИЕ КУРЕНИЯ НА ОБЩЕКЛИНИЧЕСКИЕ И БИОХИМИЧЕСКИЕ ПАРАМЕТРЫ ПАЦИЕНТОВ С ХРОНИЧЕСКИМ ПАНКРЕАТИТОМ}

Тернопольский национальный медицинский университет имени И. Я. Горбачевского МОз Украины

РЕЗЮМЕ. Хронический панкреатит (ХП) у курильщиков наблюдается в 2 раза чаще, чем у некурящих, а риск развития заболевания возрастает в зависимости от количества выкуриваемых сигарет.

Цель - исследовать влияние курения на основные общеклинические и биохимические параметры и показатели эндотоксикоза у пациентов с хроническим панкреатитом.

Материал и методы. Обследовано 64 амбулаторных пациента вне обострения: 21 - с изолированным ХП и 43 - с ХП на фоне сопутствующего курения. Диагноз устанавливали по общепринятым критериям, анамнез курения рассчитывали в единицах «пачки-годы» (одна пачка составляла 20 сигарет). Параметры общеклинического и биохимического анализа крови определяли по общепринятым в клинике методикам. Оценка эндогенной инток-

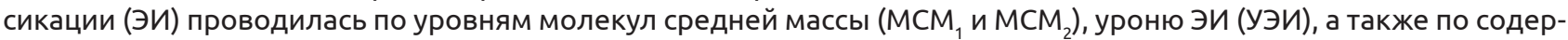
жанию циркулирующих иммунных комплексов (ЦИК) в сыворотке крови.

Результаты. Курение отрицательно влияло на клиническое течение хронического панкреатита вне обострения за счет наличия проявлений диспепсического (на 14,4 \%), болевого (на 7,5 \%) и астено-невротического (на $31,1 \%)$ синдромов у большего числа пациентов-курильщиков по сравнению с таковыми у некурящих $(p<0,05)$.

Сочетание ХП и курения способствовало углублению анемического синдрома (наличие анемии 88,37 \% в группе курильщиков против 71,42 \% в группе без курения; латентной анемии - соответственно 34,88 \% против 23,80 \%; легкой степени - 41,86 \% против 47,61 \%; средней степени - 11,63 \% в группе курильщиков при отсутствии таковой в группе некурящих) и истощению висцерального пула белка по показателю общего белка, а также более значительной интенсивности воспалительного процесса по содержанию амилазы в крови по сравнению с аналогичными параметрами некурящих пациентов.

Выводы. Установлен достоверно более високий уровень эндогенной интоксикации у пациентов с хроническим панкреатитом относительно группы контроля (на 60,71 \% - у некурящих и на 102,19 \% - у курильщиков), более высокое содержание $\mathrm{MCM}_{1}$ относительно группы здоровых в группе курильщиков против такового у некурящих - на 42,46 \% по сравнению с 30,20 \%, а также более высокий уровень циркулирующих иммунных комплексов в группе курильщиков против такового у некурящих $(p<0,05)$. Это доказало отягчающее влияние курения на течение хронического панкреатита, а также на глубину общеклинических и биохимических лабораторных параметров и показателей эндотоксикоза.

КЛЮЧЕВЫЕ СЛОВА: хронический панкреатит; курение; эндогенная интоксикация; клинические синдромы; анемия 
Огляди літератури, оригінальні дослідження, погляд на проблему, випадок з практики, короткі повідомлення

\section{INFLUENCE OF TOBACCO SMOKING ON GENERAL CLINICAL AND BIOCHEMICAL PARAMETERS OF PATIENTS WITH CHRONIC PANCREATITIS}

\section{Horbachevsky Ternopil National Medical University}

SUMMARY. Chronic pancreatitis (CP) in smokers is 2 times more common than in non-smokers, and the risk of developing the disease increases depending on the number of cigarettes smoked.

The aim - to study the effect of smoking (TS) on the main general clinical and biochemical parameters and indicators of endotoxicosis in patients with chronic pancreatitis.

Material and Methods. 64 outpatients without exacerbation were examined: 21 - with isolated CP and 43 - with CP on the background of concomitant TS. The diagnosis was established by the conventional method, the history of smoking was calculated in units of "pack-years" (one pack was 20 cigarettes). The parameters of general clinical and biochemical analysis of blood were determined according to generally accepted methods in the clinic. Evaluation of endogenous intoxication (EI) was performed on the levels of medium weight molecules (MWM1 and MWM2), the level of El (LEI), as well as the content of circulating immune complexes $(\mathrm{CIC})$ in the serum.

Results. It was found that TS adversely affected the clinical course of chronic pancreatitis without exacerbation due to the presence of manifestations of dyspeptic (14.4\%), pain (7.5 \%) and astheno-neurotic (31.1\%) syndromes in more patients-smokers compared with those of non-smokers $(p<0.05)$.

The combination of CP and TS contributed to the deepening of the anemic syndrome (the presence of anemia $88.37 \%$ in the group with TS against $71.42 \%$ in the group without TS; latent anemia - respectively $34.88 \%$ vs $23.80 \%$; mild $41.86 \%$ against $47.61 \%$, an average of $11.63 \%$ in the group of smokers in the absence of such in the group of nonsmokers) and depletion of the visceral pool of protein in terms of total protein, as well as a greater intensity of inflammation in the pancreatic amylase content in the blood compared to similar parameters in non-smoking patients.

Conclusions. Significantly higher level of endogenous intoxication of patients with chronic pancreatitis was found in the control group (60.71 \% - in non-smokers and $102.19 \%$ - in smokers), higher content of MWM1 in the group of healthy smokers compared to that in non-smokers - by $42.46 \%$ vs $30.20 \%$, as well as a higher level of circulating immune complexes in the group of smokers against that in non-smokers $(p<0.05)$. This proved the complicating effect of smoking on the course of chronic pancreatitis, as well as the depth of general clinical and biochemical laboratory parameters and indicators of endotoxicosis.

KEY WORDS: chronic pancreatitis; smoking; endogenous intoxication; clinical syndromes; anemia.

Отримано 11.10.2020 